\title{
Journal of the Marine Biological Association of India
}

\author{
A ebreviation: J. mar. biol. Ass. India
}

NEW CHARACTERS FOR CONSIDERATION

IN THE TAXONOMIC APPRAISAL OF GREY MULLETS*

\author{
G. Luther
}

Central Marine Fisheries Research Institute, Cochin-682018

\begin{abstract}
Anstract
A study of some osteological characters, namely, the parapophysial stay on the trunk vertebra, second vertebral processes, basioccipital processes, and post-zygapophysial hooks, as basic characteristics for the generic appraisal of grey mullets has revealed that these parameters can be used to separate the genera Liza, Valamugil and Ellochelon. The existence of these genera is questioned by different workers. The generic status of these three genera in relation to the genus Mugil is outlined. A new genus Osteomugil is created to accommodate $M$. cunnesius Valenciennes. The possibility that $L$. strongylocephalus, $L$. engeli and $M$. kelaartii could belong to the new genus is pointed out. The number and form of pyloric caeca provide additional help in the identification of certain species of mullets. It is suggested that species differing from others of the same genus, by having well developed adipose eyelids, be given a subgeneric status and that end of maxilla be considered as "exposed" when the mouth is closed, only when the "maxillary notch" is closer to the angle of the mouth. It is also proposed that precedence be given to osteological characters over diversity in the mouth iparts, in the taxonomic appraisal of grey mullets.
\end{abstract}

\section{INTRODUCTION}

Divergent views are on record on the status of the mugilid genera, Liza Jordan and Swain (=Chelon Rose), Valamugil Smith and Ellochelon Whitley. Schultz (1953) referred the latter two genera to the first one, whereas Thomson (1954 a) recognized Valamugil but considered Ellochelon as synonymous with Lfzat. Pillay (1962) brought these three genera under the synonymy of Mugil Linnaeus. During the course of biological studies on

* Paper presented at the IBP/PM International Symposium on Grey Mullets and their CuIture, June 2nd - 8th, 1974 Haifa, Israel.

Abstract published in the "Special Issue, Grey Mullets", Aquaculture, 5(1975): 107. 
grey mullets, the atthor however, found that based on four osteological characters these four genera could be distinguished. The characters are briefiy described and their utility in the taxonomic appraisal of grey mullets is discussed in this account, besides offering a few remarks on the systematic importance of maxilla, pyloric caeca and the adipose eyelid. Application of these characters in the classification of the other species of Indian mullets assigned to the genus Mugil by Pillay (1962) has brought to the fore the need to create a new genus so as to assign a suitable taxonomic status to Mugil cunnesius Valencien nes.

The author is thankful to Dr. E. G. Silas, Director, Central Marine Fisheries Research Institute for all the encouragement given. He thanks late Dr. K.V. Sckharan, Senior Fishery Scientist of the Institute for the valuable suggestions for the improvement of the manuscript, and Dr. M.D.K. Kuthalingam for the help given. His thanks are also due to Mr. G. Venkataraman, for supplying some nullet specimens from Mandapam.

\section{Material and Methods}

Material for this study was collected mainly at Mandapam $\left(09^{\circ} 17^{\prime} \mathrm{N}\right.$ and $\left.79^{\circ} 06^{\prime} \mathrm{E}\right)$. A few specimens were collected at Trivandrum $\left(08^{\circ} 30^{\circ} \mathrm{N}\right.$ and $\left.76^{\circ} 55^{\prime} \mathrm{E}\right)$ also. Excepting $M$. carinatus which was not avajlable for this study, the rest of the seven Indian species of grey mullets, listed herein, assigned to the genus Mugil Linnaeus by Pillay (1962) were examined, besides $V$. buchanani (Bleeker) whose occurrence in the Indian waters was considered by her as doubtful, but the validity of which has been recognized by the present author elsewhere (Luther, 1974). The eight species examined are Mugil cephalus Linnaeus, $M$. cumnesius Valencien nes, Liza macrolepis (Smith), L. parsia (Hamilton), L. tade (Forsskả), Valamugil seheli (Forsskàl), $V$. buchanani (Bleeker) and Ellochelon vaigiensis (Quoy and Gaimard). The generic names applied to the above eight species are those recognized by other authors prior to the revision of the Indian Mugilidae by Pillay (1962). The generic name Liza Jordan and Swain is used instead of Chelon Rose on the authority of Thomson (1954 a). Terminology employed here is according to Schultz $(1946,1953)$, Thomson $(1954 \mathrm{a}, \mathrm{b})$ and Springer (1968). Skeletons of over thirty specimens for each species were prepared by lightly boiling fresh fish for a few minutes for loosening the flesh from the bones. They were finally cleaned, washed and dried. Other characters were examined in over a hundred fresh and preserved fish.

\section{Oiservations and Discussion}

Investigation on the utility of the osteological and morphological characters which are detailed here with reference to the eight species has revealed that the generic position of all the species except $M$. cunnesius could be valid. Detailed discussions on each character are follows:

\section{Parapophysial stay (Fig la-e)}

Parapophysial stay, the bony bridge across the pasapophyses of the last few trunk vertebra, is absent in the three species of Liza examined, but present in the rest of the genera. It is usuaily present on the last two (10th and 11 th) trunk vertebrae in Mugil, Valamugil and the new genus, Osteomugil; 

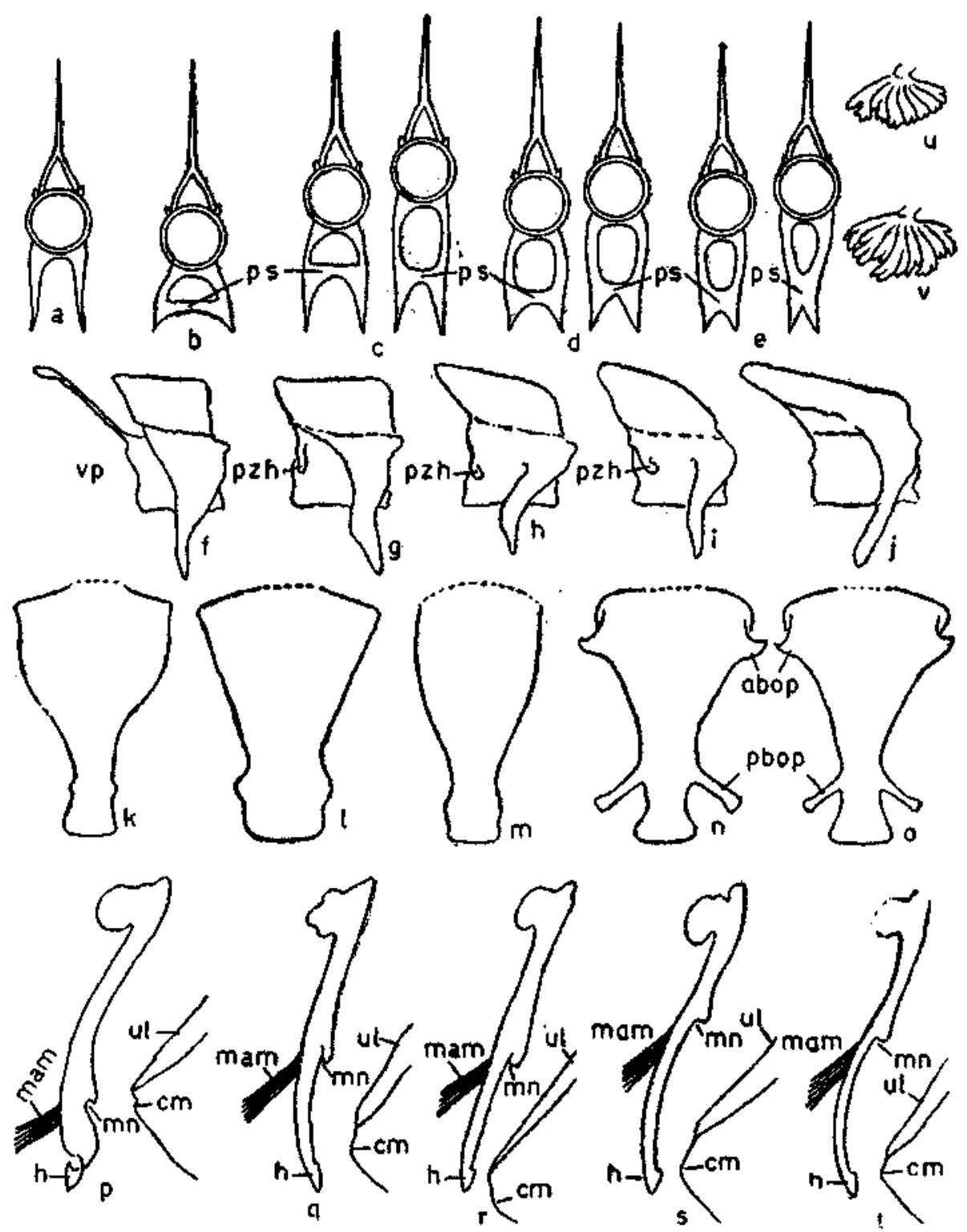

Fig. 1 a-t. Diagrammatic representation of certain osteological characters in the five genera, Liza, Ellochelon, Mugll, Valamugil and Osteommgil, the respective figures arranged in the same order in each panel. Panel 1 (top): The trunk vertebrae, II th for the first two gencra and 10th and 11 th for the rest. PS - parapophysial stay. Panel 2: The second trunk vertebia showing presence or absence of vertebral process or post zygapophysial hook. VP - Vertebral process; PZH - post zygapophysial hook. Panel 3: The basioccipital showing the presence or absence of the anterior and posterior processes. ABOP - anterior basioccipital process; PBOP - posterior basioccipital process. Panel 4: Outer aspect of maxilla and its disposition in relation to the corner of the mouth. CM - conner of mouth; MAM - major adductor muscle, MN - maxillary notch; $H$ - heel; u and v. Pyloric caeca in Valamugil buchanani and in Ellochelon vaigiensis respectively. 
but only on the last (1/th) trunk vertebra in Ellochelon. This character divides the species examined into two groups, namely, the Liza group and the non-Liza group, the latter comprising the other four genera. The 'exposed' nature of the end of maxilla when the mouth is closed (a principle for determining which is presented in a later section of this account) also forms a characteristic feature of the Liza group. Hereafter, therefore, the non-Liza group mainly enters into further discussion.

Minor variations have, however, been observed in the occurrence of the parapophysial stay within the same species. In $M$. cephalus out of over two hundred fish examined, one had this bony bridge additionally in the 9th trunk vertebra, and in another on the llth trunk vertebra only. Similarly. out of over thirty fish examined for each species, one specimen each of $V$. seheli and $V$. buchanani had this bony bridge on the 9 th trunk vertebra also; and one out of thirty-three specimens of $E$. vaigiensis also had additionally a bony bridge on the 10th trunk vertebra. But all specimens of the non-Liza group examined had the parapophysial stay on the last trunk vertebra.

\section{Second vertebral processes (Fig. I f)}

The second vertebral processes are the paired elongate structures, over the second trunk vertebra at least as high as the neural crest, one each, projecting postero-dorsally, from either side of the netral arch immediately above the neural post-zygapophysis. This character as stated earliei, is present in all the three species of the genus Liza but absent in the rest of the genera. Thomson (1954 a) reports this pair of bones to be present in the genus Liza under which he places the genus Ellochelon aiso. But the present investigation has shown the latter genus is without these processes on the second trunk vertebra.

Posterior zygapophysial hooks (Fig. I g-j)

The paired, short, stout, hook-like structures one each arising from either side of the nenral arch of the trunk vertebra at the region of the neural post-zygapophysis are the posterior zygapophysial hooks. They are present on the second and third vertebra in $M$ ugil and only on the second vertebra in Valamugil and Ellochelon. These are directed laterally, anteiorly and ventrally, respectively in the above three genera. As these hooks could be homologous to the second vertebral processes, the new genus, Osteomugil alone could be considered to have no extra process of any kind on the second or third trunk vertebra. It thus stands apart from the seven species of mullets, belonging to four genera examined. On account of this distinctive character of Mugil cumnesius Valenciennes the author proposes to remove this species from the genus $M$ ugil and place it under a new genus. As the new genus is created based on osteological difference it is named as Osteomugil gen. nov. The diagnostic characters of the new genus are given in a latter section of this account.

Basioccipital processes (Fig. $1 \mathrm{k}-0$ )

The ventrally projecting wedge-like bones, one on either side, situated anteriorly, and the laterally projecting rod-like structures, one on either side, situated posteriorly both on the basioccipital are referred to here as the basioccipital processes. One of these could be the basioccipital processes 
mentioned by Thomson (1954 a). According to him the basioccipital process is absent in Mugil. No mention of this has, however, been made by him for the gener a Liza and Valamugil. In the present study these processess were observed in Valamugil and in the new genus Osteomugil, but absent in Mugil, Ellochelon and Liza. This character would thus divide the non-Liza group into two sub-groups.

\section{Adipose eyelid}

The terms proposed by Thomson (1954 a) to describe the intrusion of this membrane over the eye as 'absent', 'obsolescent (or rudimentary)' and 'present' seem to be satisfactory. As pointed out by him this tissue does not become apparent until the fish grows to about $4-5 \mathrm{~cm}$ length even in the species where the adults have this membrane. Among the eight species examined, the adipose eyelid is present in $M$. cephalus, $L$. parsia, $L$. tade and in $O$. cunnesius; 'rudimentary' in $L$. macrolepis and "absent" in $V$. seheli $V$. buchanani and $E$. vaigiensis This variation in its occurrence in the three species of Liza now examined, suggests that the adipose eyelid is of little value as a generic character. Thomson (1954 a) also seems to express a similar view when he states, "Smith (1948) allotted this species [ Liza strongylocephalus (Richardson)] to the genus Mugil. But, despite the well developed adipose eyelid, it has teeth on pterygoids and tongue, and the maxilla is exposed; all features typical of Liza". However, the present author is of the opinion that where the occurrence of the adipose eyelid varies within the species of the same genus, for convenience the genus may be sub divided into two to place the two groups, viz., those with the adipose eyelid and those without it.

\section{Visibility of end of maxilla (Fig. I p-t)}

The visibility or otherwise of the end of maxilla when the mouth is closed, is an important character in the description of grey mullets. But the degree of visibility seems to have created considerable difficulty to those working on mullets resulting in variations in the description of this character in the same species by different authors. Besides this, descriptions on the visibility of the end of maxilla such as: "not visible or only a narrow stripe of its posterior part," "almost or quite concealed, exposed portion increases with age," "usually but not always visible," "entirely concealed or just visible," etc., are also on record. Such expressions are usually met with in the species, $M$. cephalus, $O$. cunnesius, E. vaigiensis and $L$. strongylocephalus. The author also found it difficult to describe precisely this condition in the first three species. The structure and disposition of the maxilla itself present these difficulties.

ln some species, however, the end of maxilla is distinctly 'exposed" when the mouth is closed, giving no room for doubt. Liza macrolepis, $L$. parsia and $L$. tade examined in this study fall under this group. The following particulars regarding the structure and disposition of the maxilla of $L$. macrolepis will illustrate as to how the end of maxilla gets distinctly exposed: When the outer aspect of the right maxilla is viewed 'in situ' after depressing the lower jaw, it could be seen to extend posteroventrally up to about the corner of the mouth, then to take a clock-wise twist and end in a slightly enlarged heel. A'bulge' and the associated 'notch' are seen on the anterior face of the maxilla where it takes the inward twist. The distal 
portion of the maxilla is broader and this condition is further augmented by the presence of the very thick tissue that covers it. Although this tissue slightly obscures the notch, the latter could be readily located since the major adductor maxillae is inserted close to the 'bulge'. Similar condition is met with in the other two species of Liza examined. In the other genera, however, the portion further down the notch is not broader, but it takes very little twist, and gently curves backward ending in a slightly bulged heel. As the distal portion of the maxilla is not broad and twisted as in Liza, this portion becomes scarcely visible when the mouth is closed. In the doubtful cases, as mentioned earlier, the end of maxilla is not exposed to view if the upper and lower jaws ate pressed together hard. Under this circumstance the visibility of the end of maxilla when the mouth is closed loses its taxonom ic value. Therefore it is suggested that the end of maxilla may be considered as 'exposed' when the mouth is closed, only if this condition is associated with the close proximity of the maxillary notch to the corner of the mouth.

\section{Pyloric caeca}

The number of pyloric caeca in the different species of mullets under reference as observed by previous authors and by the present author are given in Table 1.

TABLE 1. Number of pyloric caeca

\begin{tabular}{|c|c|c|}
\hline Species & $\begin{array}{l}\text { No. of pyloric caeca recorded } \\
\text { by previous workers }\end{array}$ & $\begin{array}{l}\text { No, of caeca as observed } \\
\text { by the present author }\end{array}$ \\
\hline (Mugil cephalts) & $\begin{array}{l}\text { 2: Gunther (1861) \& Thomson (1954 a) } \\
\text { 5: Rahimulla (1945) }\end{array}$ & 2 \\
\hline Liza parsia & 5: Day (1878) \& Rahimulla (1945) & $5-6$ (usually 5 ) \\
\hline L. rade & 5: Day (1889) \& Pillay (1953) & 5 \\
\hline L. macrolepis & 4: Day (1878) & 5 \\
\hline Valamugil seheli & 2: Thomson (1954 a) & $6-9$ (ustally $7-8$ ) \\
\hline V. buchanani & $\longrightarrow$ No record & $6-9$ (usually $7-8$ ) \\
\hline Ellochelon vaigiensis & 10 : Gunther (1861) \& Day (1878) & $6-9$ (usually 7$)$ \\
\hline Osteomugit cunnesius & 2: Rahimulla (1945) & $6-7$ (usually 6 ) \\
\hline $\begin{array}{l}(=M . \text { cunnesius }) \\
(=M . \mid \text { speilgeri })\end{array}$ & 6: Day (1878) & \\
\hline
\end{tabular}

As the distal portion of each caecum has been found to be irregularly branched in $V$. buchanani (fig. 1 u) and $E$. vaigiensis (fig. 1 v) and entire in the rest of the species examined, the count of the caeca for the for egoing two species was made at their origin from the duodenum.

Although the range in the number of pyloric caeca in the five genera under reference has been found to be narrow and definite, it is seen from 
the review of Thomson (1966) that the number of caeca range between 2 and 22 in the genus Mugil and between 2 and 17 in Liza. However, it would appear that the number of pyloric caeca in relation to other characters could aid in the generic appraisal of the grey mullets.

\section{Osteomugil Gen. nov.}

\section{Type Genus: Mugil cunnesius Valenciennes}

Mouth terminal, lips thin, the lower projecting horizontally, but not folded downwards. No papillae, lamellae or posterior folds in the lips. Lower lip with a double symphysial knob. Premaxilla straight. Maxilla bent down slightly posteriorly, the weak notch present on it being far away than the posterior end of maxilla to the corner of mouth (posterjor end of maxilla not exposed when the mouth is closed). Preorbital denticulate, with its anterior edge concave or slightly emarginate, its hind end truncate, equal to or less than the distance between nostrils in width. Nostrils in line with the upper edge of the orbit, widely spaced, the anterior one being closer to the groove behind upper lip than to posterior nostril. Adipose eyelid present. Pectoral fins long, longer than head without snout. A pointed, elongate scale present in axil of peztroal fits. Anal origin well in advance of second dorsal origin. Caudal moderately forked.

Pyloric caeca 6-7. Gut includes a gizzard. Parapophysial stay present on IOth and IJth trunk vetebrae. Basioccipital processes present. Second vertebral processess and posterior zygapophysial hooks on trunk vertebra absent.

Remarks: The new genus bears some affinity to Valamugil as brought out in the key to the genera. The differentiating characters are also given in the key. If adipose eyelid could be considered as of any generic value, the new genus, the characters of which as now understood based on the single species, could be readily distinguished from Valamugil in having the well developed adipose eyelid. A perusal of the descriptions of Liza strongylocephalus (Richardson), $L$. engeli (Bleeker) and $M$. kelaartii Gunther indicates the possibility of these species to belong to the new genus.

\section{Osteomugil cunnesius (Valenciennes)}

Synonymy, description and distribution : Pillay (1962)

\section{Key to the Five Genera Mentioned in this Account}

1a. Parapophysial stay on trunk vertebra absent, second vertebral processes present. Distal portion of maxilla broader, twisted inward and with a deep notch, corner of mouth being closer to this notch than to end of maxilla (end of maxilla exposed when mouth in closed). ......Liza

1b. Parapophysial stay on trunk vertebra present. Second vertebral processes absent. Distal portion of maxilla nearly straight, corner of mouth closer to end of maxilla than to maxillary notch (end of maxilla not exposed when mouth is closed). 
2a. Parapophysial stay usually on 11 th trunk vertebra (rarely on 10th a Iso). Space between nostrils less than that between the anterior rostril and the groove behind the upper lip. Pectoral axillary scale absent Ellochelon

2b. Parapophysial stay usually on 10th and 1 ith trunk vertebrae (rarely on 11 th alone or on 9th also). Space between noitrils more than that between the anterior nostril and the groove behind the upper lip. Pectoral axillary scale present.

3a. Basioccipital processes absent. Preorbital nearly straight, not extending beyond corner of mouth; its width at rear end narrow and less than half the space between nostrils. Pectorals short, less than the length of head without snout. Mugil

3b. Basioccipital processes present. Preorbital curved or slightly emarginate, tip truncate, extending beyond corner of mouth; width at tip more than half the space between nostrils. Pectorals long, more than the length of head without snout.

4a. Posterior zygapophysial hooks present on trunk vertebra (2nd). Anal fin starts opposite of second dorsal. Caudal deeply forked. Adipose eyelid absen t..................................................... Valamugil

4b. Posterior zygapophysial hooks absent on any trunk vertebra. Anal fin starts clearly in advance of 2 nd dorsal. Caudal fork not deep. Adipose eyelid present, broad posteriorly than anteriorly. Osteomugil

\section{CONCLUSION}

The present investigation on some of the osteological features has indicated that anatomically the grey mullets are not as uniform a group as presumed by earlier workers, and that osteological characters could be of much use in their generic appraisal in spite of the diversity in the mouth parts exhibited by some species of mullets. In this account it is shown that the eight species belonging to five genera fall into two major groups: those with the parapophysial stay on trunk vertebra and those without it. Thus, from further osteological studies, it would be possible to assign the various species of grey mullets to some basic groups. It is felt that a study of the evolutionary diversity in the mouth parts with the background knowledge of these major basic osteological groups could provide a sound basis for the generic appraisal of grey mullets. There is an urgent need for coordinated studies on grey mullets world over, with a view to evolve a consensus as to the characters of generic value for a correct appraisal of the generic status of the different species of grey mullets.

\section{REFERENCES}

DAY, F. 1878. Fishes of India. 2 Vols., London.

1889. Fatna of Britlsh Indla. Fishes, 2 Vols. London.

Guniter, A. 1861. Cotalogue of Acanthopterygian Fishes in the British Museum, 3. 
LuthFr, G. 1974. On the little know mullet, Valamugil buchanani (Bleeker) (Mugilidae: Pisces) in the Indian waters. J. mir. biol. Ass, India, 16 (1): 290-291.

PIllay, S. R. 1962. A revision of Indian Mugilidae, J. Bombay Nat. Hist. Soc., 59(1): 254-270 and 59 (2): 547-576.

PILLAY, T.Y.R. 1953. Studies on the food, feeding habits and alimentary tract of the grey mullet, Mugil tade Forsskal. Proc. Nat. Inst. Sci. India. Calcutra, 19(6): 777-827.

RaHimulla, M. 1945. A comparative study of the morphology, histology and probable functions of the pyloric caeca in Indian fishes, together with a discussion on their homology. Proc. Indian. Acad. Sci., Bangalore, 21 B: 1-37.

SCHCLITZ, L. P. 1946. A revision of the genera of mullets, fishes of the family Mugilidae, with descriptions of three new genera. Proc. U.S. INat. Mus., 96: 377-395.

1953. Fishes of tite Marshall and Marjanas lslands. Bull. Smith. Inst. U.S. Nat. Mus., 202(1).

Sмıтн. J. L. B. 1948. A generic revision of the mugilid fishes of South Africa. A.th. Mag. Nat. Hist., 14 (11): 833-843.

SPRINGer, V. G. 1968. Osteology and Classification of fishes of the family Blenniidae. Bull. Smith. Inst. U.S. Nat. Mus, 284.

Thomson, J. M. 1954 a. The Mugilidae of Australia and adjacent seas. Austr. J. Mar. Freshw. Res., 5(1): 70-131.

1954 b. The organs of feeding and food of some Australian mullet. Ibid., 5(3): 469-485.

1966. The grey mullets. Oceanogr. Mar. Biol Ann. Rev., 4: 301-335. In: Harold Barnes (Ed.). George Allen and Allen and Unwin Ltd., London. 